P-ISSN: 2615-1723

E-ISSN: 2615-1766

Oktober 2018
Jurnal Riset Pendidikan Dasar

01 (2), ( 2018) 107-115

Submitted: Agustus, Accepted: September, Published: Oktober

\title{
PENGARUH MODEL PEMBALAJARAN NUMBERED HEADS TOGETHER TERINTEGRASI KARAKTER RASA INGIN TAHU TERHADAP PRESTASI BELAJAR MATEMATIKA
}

\author{
Firmansyah \\ Program Studi Pendidikan Guru Sekolah Dasar, FISKEP Universitas Hein Namotemo, Indonesia \\ Korespondensi. E-mail: firmansyahbilingua1010@gmail.com
}

\begin{abstract}
Abstrak
Pengintegrasian karakter dalam pembelajaran dilakukan untuk mencegah terjadinya degradasi nilai-nilai etika dan moral dikalangan remaja. Penelitian ini bertujuan untuk mengetahui pengaruh model pembelajaran Numbered Heads Together terintegrasi karakter rasa ingin tahu terhadap prestasi belajar matematika siswa kelas IV SD. Penelitian ini merupakan penelitian eksperimen. Populasi dalam penelitian ini adalah seluruh siswa kelas IV SDN Petompon 01 Kota semarang. Tehnik pengambilan sampel yang digunakan adalah cluster sampling. Sampel pada penelitian ini adalah kelas IV A dan Kelas IV B. Tehnik pengumpulan data yang digunakan adalah lembar penilaian validator, tes hasil belajar dan lembar pengamatan karakter. Tehnik analisis data yang digunakan adalah analisis data kevalidan perangkat pembelajaran, analisis data instrument tes hasil belajar dan uji pengaruh. Hasil analisis data : 1) Perangkat pembajaran matematika yang telah diimpementasikan valid berdasarkan penilaian ahli, 2) terdapat 14 butirsoal yang akan digunakan untuk mengukur prestasi belajar siswa, 3) uji pengaruh model pembelajaran Numbered Heads Together terintegrasi karakter rasa ingin tahu terhadap prestasi belajar posttest dengan menggunakan uji regresi sederhana diperoleh nilai sig. $=$ 0,000 dimana $0,000<0,05$ sehingga $\mathrm{H}_{0}$ ditolak. Artinya terdapat pengaruh karakter rasa ingin tahu $(\mathrm{X})$ terhadap prestasi belajar posttest $(\mathrm{Y})$. Selain itu diperoleh persamaan regresi $\widehat{Y}=-26,291$ $+1,311 \mathrm{x}$. Persamaan regresi dijadikan sebagai dasar prediksi prestasi belajar posttest (Y) jika diketahui karakter rasa ingin tahu (X).
\end{abstract}

Kata Kunci:Numbered Heads Together, Karakter Rasa InginTahu, Prestasi BelajarMatematika

\section{INFLUENCE OF NUMBERED HEADS TOGETHER LEARNING MODEL INTEGRATED CHARACTER OF CURIOSITY TO MATHEMATICS LEARNING ACHIEVEMENT}

\begin{abstract}
Integrating the characters in learning is done to prevent the degradation of ethnical and moral values among adolescents. This research aims to determine the effect of Numbered Heads Together integrated the character of curiosity to the mathematics learning achievement $4^{\text {th }}$ grade in elementary school. This research is an experimental research. The population of research is all fourth grade students of SDNPetompon 01 Kota Semarang. The sampling technique used is cluster sampling. The sample of research is class IV A and Class IV B. Data collection techniques used validator assessment sheets, learning result test and character observation sheet. Data analysis technique used is
\end{abstract}

Copyright (C2018, JRPD, ISSN 2615 - 1723 (Print), ISSN 2615 - 1766 (Online) 
data analysis of validly learning device, analysis of test instrument data of learning result and influence test. Results of data analysis: 1) Mathematical learning tools that have been implementaton validly based on expert assessment, 2) there are 14 items that will be used to measure student achievement, 3) test of influence model of learning Numbered Heads Together integrated curiosity character to learning achievement posttest by using simple regression test obtained by sig value. $=0,000$ where $0,000<0,05$ so $\mathrm{HO}$ is rejected. This means there is the influence of the character of curiosity $(X)$ on learning achievement posttest $(Y)$. Besides, we get regression equation $Y=-26,291+1,311 x$. The regression equation is used as the basis for prediction of posttest learning achievement $(Y)$ if known the character of curiosity $(X)$.

Keywords: Numbered Heads Together, Character of Curiosity, Mathematics Learning Achievement

\section{PENDAHULUAN}

Pendidikan di indonesia telah mengalami peningkatan sejalan dengan program pembangunan pendidikan yang mulai terprogram sejak 40 tahun yang lalu. Namun fakta menunjukkan bahwa pendidikan nasional menghadapi tantangan untuk mewujudkan keunggulan persainganantar bangsa dalam percaturan global. Hal tersebut didukung oleh pemaparan Human Development Indeks (HDI) yang memposisikan Indonesia pada peringkat 124 pada tahun 2012 atau menurun 13 angka dari peringkat 108 tahun 2005.

Indonesia juga tergabung dalam Trends International Mathematics and Sience Study (TIMMS) sejak tahun 1999 dan Program for International student Asessment (PISA) sejak tahun 2000. Nizam dalam Kompas (2016) mengungkapkan hasil TIMSS 2015:Berdasarkan survey yang dilakukan di Indonesiaterkaitkemampuan Matematika dan Sains siswa kelas IV SD. Indonesia beradapadaposisi bawahdengan Skor Matematika 397, Hal tersebutmenempatkan Indonesia di nomor 45 dari 50 negara.

Hal serupaterjadi pula pada peringkat Indonesia di PISA. Kemampuan anak Indonesia berusia 15 tahun dalam matematika, sains dan membaca masih berada pada peringkat ke-63 dari 69 negara yang turutserta dalam PISA pada tahun 2015. Peringkattersebuttidakmeningkatsecarasignifik andengan survey padatahun 2012.Rata-rata skor matematika, membaca dan sains anak anak Indonesia adalah 386, 397, 403, sangatjauhjikadibandingkan rata-rata skor anak di negara OECD, yaitu 490, 493, 493 (PISA, 2015).

Pembangunan kualitas pendidikan tidak dapat dilepaskan dari pembangunan karakter. Pembangunan karakter yang merupakan implementasi amanat Pancasila sertaPembukaan UUD 1945 dilatar belakangi oleh realita permasalahan kebangsaan yangberkembang saat ini, seperti: disorientasi dan belum tertanamnya nilai-nilai Pancasila;keterbatasan perangkat kebijakan terpadu dalam mewujudkan nilai-nilai Pancasila;bergesernya nilai etikadan moral dalam kehidupan berbangsa dan bernegara; memudarnyakesadaran terhadap nilai-nilai luhurbudaya bangsa; munculnya disintegrasi bangsa; danmelemahnya kemandirian bangsa. Wibowo (2010) mengungkapkan :Contoh nyata ialah 158 kepala daerah tersangkut penyelewengananggaran sepanjang 2004-2011, 42 anggota DPR masukdalampusaran korupsi pada kurun waktu 2008-2011, 30 anggota DPR periode 1999-2004 terlibat penyuapan pemilihan DGS BI. Kasus korupsi terjadi diberbagai lembaga tinggi Negara seperti KPU, KY, KPPU, Ditjen Pajak, BI, dan BKPM.

Integrasi pendidikan karakter pada kurikulum dewasa ini yaitu memasukkan lebih dari 3 nilai karakter pada satu kompetensi dasar atau materi pokok sehingga tidak terfokus. Integrasi karakter bersifat sebagai tempelan sehingga belummampumenanamkan pembentukan karakter di SD. Hasil penelitian Suharto (2013), Mulyana (2013), Pujiastuti (2012) menunjukkan bahwa integrasi karakter dengan fokus memetakan satu karakter dengan satu materi pokok atau KD dapat menghasilkan peningkatan karakter bagi siswa. 
Selain fokus, integrasi karakter pada kurikulum matematika perlu bersifat berjenjang dan spiral sehingga terjadi pembiasaan bagi siswa terhadap proses internalisasi indikator nilai karakter.

Integrasi karakter dalampembelajaran perlu ditunjang dengan model pembelajaran yang tepat sehingga pendidikan karakter dapat berkembang maksimal disertai dengan hasil belajar yang baik. Rusilowati (2012) mengungkapkan bahwa guru perlu mengenal berbagai model pembelajaran, agar dapat mengintegrasikan moral kedalam mata pelajaran. Model-model Pembelajran kooperatif dinilai tepat digunakan dalam mendukung integrasi pendidikan karakter di sekolah. Lickona (2013)berpendapat bahwa pembelajaran kooperatif mengajarkan nilai moral dan akademik sekaligus.

Pembelajaran kooperatif merupakan pembelajaran yang sangat berkembang pesat dalam dunia pendidikan saat ini. Pembelajaran kooperatif memberikan siswa kesempatan besar untuk belajar bersama siswa lainnya. Dewey (Huda, 2013) menuturkan bahwa dengan interaksisosial, siswa akan menerima feedback atas segala aktivitas yang mereka lakukan, mereka akan belajar bagaimana berperilaku dengan baik, dan mereka akan memahami apa yang harus dilakukan dalam kerja kelompok serta kooperatif. Lickona (2013) menambahkan bahwa proses belajar kooperatif dapat diteliti dan terbukti efektif dan dapat diterapkan disemua level.Berdasarkan uraian di atas, peneliti menarik kesimpulan bahwa penelitian yang bertujuan untuk pengintegrasian pendidikan karakter denganpembelajaran matematika SD berbasis pembelajaran kooperatif ini sangat dibutuhkan. Hal ini diupayakan sebagai solusi dari degradasi karakter siswa di Indonesia yang mulai tampak.

Berdasarkan latar belakang diatas, tujuan penelitian ini adalah untuk mengetahui pengaruh dari penerapan pembelajaran kooperatif tipe Numbered Heads Together terintegrasi pendidikan karakter pada pembelajaran matematika SD.

\section{METODE}

\section{Pendekatan dan Desain Penelitian}

Pendekatan penelitiandalamini adalah pendekatan kuantitatif. Jenis penelitian ini adalah penelitian eksperimen. Desain penelitian merupakanNonequivalent Control Grop Design, yang merupakan salah satu bentuk desain penelitian dari Quasi Experimental Design. Desain penelitian ini adalah pengembangan dari true Experimental Desaign. Desain ini dipilih karena dalam penelitian pendidikan, peneliti akan sulit mengontrol variabel lain yang mempengaruhi pelaksanaan eksperimen.

Keterangan :

$\begin{array}{ll}\mathrm{E}_{1} & \text { : Kelas Eksperimen } \\ \mathrm{E}_{2} & \text { : Kelas Kontrol } \\ \mathrm{X}_{1} & \text { : Perlakuan/Treatmen yang diberikan } \\ & \begin{array}{l}\text { kepada kelas eksperimen } \\ \text { (Pembelajaran Kooperatif Tipe }\end{array} \\ & \text { Numbered Heads Together terintegrasi } \\ & \text { Karakter rasa ingin tahu) } \\ \mathrm{X}_{2} & \text { : Perlakuan/Treatmen yang diberikan } \\ & \text { kepada kelas kontrol (Pembelajaran } \\ & \text { Konvensional) } \\ \mathrm{O}_{1} & \text { : Pretest kelas eksperimen } \\ \mathrm{O}_{2} & \text { : Pretest kelas kontrol } \\ \mathrm{O}_{3} & \text { : Posttest kelas eksperimen } \\ \mathrm{O}_{4} & \text { : Posttest kelas control }\end{array}$

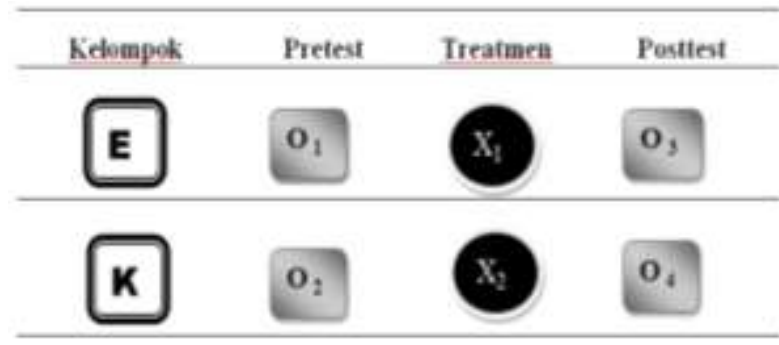

Tabel 1. Desain Penelitian

\section{Populasi dan Sampel}

Populasi dalam penelitian eksperimeniniadalahdari seluruh siswa kelas IV SDNegeri Petompon 01 Kota Semarang yang terdiri dari 54 siswa yang terbagi menjadi

Copyright O2018, JRPD, ISSN 2615 - 1723 (Print), ISSN 2615 - 1766 (Online) 
dua kelas yaitu kelas IV A dan kelas IV B. Pengambilan sampel dilakukan menggunakan teknik Cluster Sampling. Teknik Cluster Random Sampling merupakan salah satu jenis dari Probability sampling. Berdasarkan proses tersebut maka terpilih kelas IV A Sebagai kelas kontrol dan IV A sebagai kelas eksperimen.

\section{Tehnik dan Instrumen Pengumpulan Data}

Tehnik dan instrumen pengumpulan data pada penelitian ini terdiri dari :

a. Lembar Penilaian Validator

Lembar penilaian validator pada penelitian ini bertujuan untuk mendapatkan data tentang validitas perangkat pembelajaran yang terdiri dari silabus, Rencana Pelaksanaan Pembelajaran (RPP), Lembar Kerja Siswa (LKS), Bahan Ajar, Tes Hasil Belajar, lembar pengamatan psikomotor dan karakter untuk satu materi pokok. Perangkat pembelajaran yang telah valid diterapkan pada kelas eksperimen.

b. Tes Hasil Belajar

Tes hasil belajar siswa dijadikan salah satu acuan untuk memperoleh informasi pengaruh model pembelajaran kooperatif Numbered Heads Together terintegrasi karekter rasa ingin tahu terhadap prestasi belajar matematika. Tes hasil belajar disusun berdasarkan indikator pembelajaran kompotensi dasar (Kompetensi Inti 3) dari silabus matematika SD terintegrasi dengan pendidikan karakter berbasis Pembelajaran Kooperatif yang telah valid.

c. Lembar Pengamatan Psikomotor

Lembar pengamatan psikomotor siswa dijadikan salah satu acuan untuk memperoleh keefektivan perangkat. Lembar pengamatan psikomotor disusun berdasarkan indikator pembelajaran kompetensi dasar (Kompetensi Inti 4) dari silabus matematika SD terintegrasi dengan pendidikan karakter berbasis Pembelajaran Kooperatif telah valid.

\section{d. Lembar Pengamatan Karakter}

Lembar pengamatan karakter siswa dijadikan satu acuan untuk memperoleh informasi pengaruh pembelajaran kooperatif
Numbered Heads Together terintegrasi karekter rasa ingin tahu terhadap prestasi belajar matematika. Lembar pengamatan karakter disusun berdasarkan pengembangan indikator karakter yang terdapat pada silabus matematika SD yang terintegrasi dengan pendidikan karakter berbasis Pembelajaran Kooperatif telah valid.

\section{Tehnik Analisis Data}

1. Analisis Data kevalidan perangkat pembelajaran

Kevalidan perangkat pembelajaran menggunakan pengujian internal yaitu pendapat ahli (expert review) terhadap perangkat. Pengujian dilakukan dengan beberapa kali sampai ditemukan rancangan perangkat yang valid. Pengujian pendapat ahli (expert review) dilakukan dengan meminta pendapat para ahli serta praktisi yang berjumlah 5 orang. Tingkat kevalidan perangkat pembelajaran yangtelah dikembangkan diukur dengan teknik analisis sebagai berikut :

$$
\begin{aligned}
& \text { Rataan Skor Validasi Perangkat } \\
& =\frac{\text { Rataan Jumlah Validator tiap Aspek }}{\text { Banyak aspek penilaian }}
\end{aligned}
$$

Kategori kevalidan perangkat pembelajaran dibuat dalam kategori seperti pada Tabel 2 berikut ini.

Tabel 2. Pedoman Penilaian Kevalidan Perangkat Pembelajaran

\begin{tabular}{cc}
\hline Interval rata-rata Skor & Kategori \\
\hline $1,0 \leq$ rata-rata $\leq 1,75$ & Kurang \\
\hline $1,75<$ rata-rata $\leq 2,50$ & Cukup \\
\hline $2,50<$ rata-rata $\leq 3,25$ & Baik \\
\hline $3,25<$ rata-rata $\leq 4,00$ & Sangat Baik \\
\hline
\end{tabular}

Perangkat Pembelajaran dapaydikatakan valid jika rerata skor penilaian semua validator terhadap perangkat pembelajaran berada pada kategori baik atau sangat baik.

2. Analisis Data Instrumen Tes Hasil Belajar Copyright (C2018, JRPD, ISSN 2615 - 1723 (Print), ISSN 2615 - 1766 (Online) 
Analisis butir tes dilakukan untuk menentukan kualitas soal dari tes hasil belajar matematika siswa. Analisis butir tes yang dilakukanterdiridari validitas, reliabilitas, taraf kesukaran, dan daya pembeda.

3. Uji Pengaruh Karakter terhadap Prestasi Belajar

Untuk mengetahui adaatautidaknya pengaruh antara karakter siswa terhadap prestasi belajar siswa secara signifikan dengan menggunakan pembelajaran matematika SD yang terintegrasi dengan pendidikan karakter berbasis pembelajaran kooperatif pada kelas eksperimen maka akan dilakukan pengambilan data melalui lembar pengamatan karakter. Pada bagian ini variabel pada uji pengaruh yang pertama ada dua yaitu variabel independen (X) dan variabel dependen prestasi belajar posttest (Y). Uji pengaruh yang digunakan adalah analisis regresi sederhana dengan dengan bantuan SPSS Statistics 23.0. Hipotesis yang telahdirumuskan sebagai berikut:

$H_{0}: \beta=0$ ( tidak ada pengaruh linier variabel $\mathrm{X}$ terhadap variabel $Y$ )

$H_{1}: \quad \beta \neq 0 \quad$ (ada pengaruh linier variabel $\mathrm{X}$ terhadap variabel $Y$ )

Langkah berikutnya adalah melakukan analisis regresi. Untuk menguji hubungan pengaruh, digunakan persamaan regresi dengan rumus :

$$
\begin{gathered}
\mathrm{b}=\frac{\sum x_{\mathrm{i}} y_{\mathrm{i}}-\left(\sum x_{\mathrm{i}}\right)\left(\sum y_{\mathrm{i}}\right) / n}{\sum x_{\mathrm{i}}^{2}-\left(\sum x_{\mathrm{i}}\right)^{2}}=\frac{n \sum x_{\mathrm{i}} y_{\mathrm{i}}-\left(\sum x_{\mathrm{i}}\right)\left(\sum y_{\mathrm{i}}\right)}{n \sum x_{\mathrm{i}}^{2}-\left(\sum x_{\mathrm{i}}\right)^{2}} \\
\mathrm{dan} \mathrm{a}=\bar{y}-\mathrm{b} \bar{x} \\
\widehat{\mathrm{Y}}=a+b X \\
\text { Sukestiyarno (2014: 165) }
\end{gathered}
$$

\begin{tabular}{|c|c|c|c|c|c|c|c|c|}
\hline \multirow{2}{*}{ No } & \multirow{2}{*}{ Perangkat } & \multicolumn{5}{|c|}{ Rata-Rata Skor Validator } & \multirow{2}{*}{$\begin{array}{l}\text { Rata- } \\
\text { Rata }\end{array}$} & \multirow{2}{*}{ Kategori } \\
\hline & & V 1 & V 2 & V 3 & V 4 & V 5 & & \\
\hline 1 & Silabus & 3,42 & 3,83 & 3,67 & 3,50 & 3,25 & 3,53 & Sangat Baik \\
\hline 2 & RPP & 3,21 & 3,57 & 3,43 & 3,64 & 3,29 & 3,43 & Sangat Baik \\
\hline 3 & LKS & 3,67 & 3,67 & 3,00 & 4,00 & 3,00 & 3,47 & Sangat Baik \\
\hline 4 & Bahan Ajar & 3,25 & 3,63 & 3,75 & 3,38 & 3,38 & 3,48 & Sangat Baik \\
\hline 5 & Tes Hasil Belajar & 3,33 & 3,67 & 3,67 & 3,83 & 3,67 & 3,63 & Sangat Baik \\
\hline 6 & $\begin{array}{l}\text { Lembar Pengamatan } \\
\text { Psikomotor }\end{array}$ & 3,25 & 3,25 & 3,75 & 3,75 & 3,25 & 3,45 & Sangat Baik \\
\hline 7 & $\begin{array}{c}\text { Lembar Pengamatan } \\
\text { Karakter }\end{array}$ & 3,00 & 3,25 & 3,75 & 3,50 & 3,00 & 3,30 & Sangat Baik \\
\hline
\end{tabular}

Tabel 3. Hasil Kevalidan Perangkat Pembelajaran

Copyright $\odot 2018$, JRPD, ISSN 2615 - 1723 (Print), ISSN 2615 - 1766 (Online) 


\section{Analisis Data Instrumen Tes Hasil Belajar}

Rekapitulasi hasilanalisis tes hasil belajar pada penelitian ini dilakukan untuk menentukan soal yang akan digunakan pada tes hasil belajar. Rancangan tes hasil belajar pada proses ini akan diimplemntasikan pada kelas IV A (kelas kontrol) dan kelas IV B (Kelas eksperimen) untuk mengukur kemampuan kognitif siswa terkait materi pokok pengukuran sudut. Rekapitulasi analisis butir soal tes hasil belajar dapat dilhat pada tabel 4 berikut.

Tabel 4. Hasil Analisis Data Instrumen Hasil Pembelajaran

\begin{tabular}{|c|c|c|c|c|c|}
\hline Butir Soal & Validitas & Reliabilitas & $\begin{array}{c}\text { Tingkat } \\
\text { Kesukaran }\end{array}$ & Daya Beda & Kesimpulan \\
\hline Nomor 1 & Cukup & \multirow{15}{*}{ Sangat Tinggi } & Mudah & Cukup & Dipakai \\
\hline Nomor 2 & Cukup & & Sedang & Sangat Baik & Dipakai \\
\hline Nomor 3 & Cukup & & Sedang & Cukup & Dipakai \\
\hline Nomor 4 & Cukup & & Sedang & Cukup & Dipakai \\
\hline Nomor 5 & Cukup & & Sedang & Sangat Baik & Dipakai \\
\hline Nomor 6 & Tinggi & & Sedang & Baik & Dipakai \\
\hline Nomor 7 & Tinggi & & Sedang & Baik & Dipakai \\
\hline Nomor 8 & Tinggi & & Sedang & Sangat Baik & Dipakai \\
\hline Nomor 9 & Cukup & & Sedang & Cukup & Dipakai \\
\hline Nomor 10 & Tinggi & & Sedang & Sangat Baik & Dipakai \\
\hline Nomor 11 & Sangat Rendah & & Mudah & Jelek & Tidak Dipakai \\
\hline Nomor 12 & Cukup & & Sedang & Baik & Dipakai \\
\hline Nomor 13 & Tinggi & & Sedang & Baik & Dipakai \\
\hline Nomor 14 & Tinggi & & Sukar & Baik & Dipakai \\
\hline Nomor 15 & Cukup & & Sedang & Baik & Dipakai \\
\hline
\end{tabular}

Berdasarkan analisis butir soal yang telah dilakukan dapat disimpulkan bahwa pada penelitian ini peneliti akan menggunakan 14 butir soal pada tes hasil belajar yaitu $1,2,3,4,5,6,7,8,9,10,12,13,14, \quad$ dan 15 sedangkan butir soal no 11 tidak dapat digunakan karena memiliki validitas rendah dan daya pembeda jelek.

\section{Uji Pengaruh Karakter Terhadap Prestasi Belajar}

Sebelum dilakuk ananalisis data ujiregresi, terlebih dahulu dilakukan uji prasyarat yang terdiri dari uji normalitas dan uji homogenitas.

Hipotesis untuk uji normalitas dirumuskan sebagai berikut:

$\mathrm{H}_{0} \quad$ :Data nilai Posttest siswa kelas eksperimen berdistribusi normal
$\mathrm{H}_{1} \quad$ : Data nilai Posttest siswa kelas eksperimen tidak berdistribusi normal

Uji normalitas pada tahap ini dilakukan dengan menggunakan uji Kolmogorov - Smirnov dengan bantuan SPSS Statistics 23.0. Taraf kesalahan yang digunakan adalah $\alpha=0,05$. Kriteria pengujiannya $\mathrm{H}_{0}$ diterima apabila signifikansi> 0,05 artinya populasi berdistribusi normal.

Hasil uji normalitas posttest siswa kelas Eksperimen dapat dilihat pada tabel 5

Berdasarkan hasil yang diperoleh pada tabel 4.16, uji normalitas nilai posttest kelas eksperimen dengan menggunakan uji Kolmogorov - Smirnov diperoleh nilai signifikansi $=0,200$ dimana $0,200>0,05$ sehingga $\mathrm{H}_{0}$ diterima. Artinya data nilai Posttest siswa kelas eksperimen berdistribusi normal. 
Tabel 5. HasilUjiNormalitas Posttest siswakelaseksperimen

\begin{tabular}{cccr}
\hline & \multicolumn{3}{c}{ Kolmogorov-Smirnov } \\
\cline { 2 - 4 } & Statistic & Df & Sig. \\
\hline $\begin{array}{c}\text { Posttest_I } \\
\text { VB }\end{array}$ &, 124 & 27 &, $200^{*}$ \\
\hline
\end{tabular}

Uji asumsi prasyarat yang kedua adalah uji homogenitas. Uji homogenitas pada penelitian ini dilakukan dengan melihat nilai kurtosisnya. Berdasarkan hasil analisis uji homogenitas diperoleh nilai kurtosis adalah 1,047. Nilai tesebut menunjukkan nilai negative dekat dengan nol sehingga dapat disimpulkan bahwa data posttest siswa kelas eksperimen cenderung homogen.

Setelah uji prasyarat terpenuhi, maka analisis dilanjutkan pada uji pengaruh. Uji pengaruh bertujuan untuk menguji adanya pengaruh karakter rasa igin tahu terhadap prestasi belajar posttest kelas eksperimen. Variabel pada uji pengaruh yang pertama ada dua yaitu variabel independen karakter rasa ingin tahu $(\mathrm{X})$ dan variabel dependen prestasi belajar posttest (Y).Uji pengaruh yang digunakan adalah analisis regresi sederhana dengan dengan bantuan SPSS Statistics 23.0.

Hipotesisdirumuskan sebagai berikut:

$H_{0} \quad: \beta=0$ ( tidak ada pengaruh linier variabel $\mathrm{X}_{1}$ terhadap variabel $Y$ )

$H_{1}: \quad \beta \neq 0$ ( ada pengaruh linier variabel $X$ terhadap variabel $Y)$

Taraf signifikansi yang digunakan adalah $\alpha=0,05$. Kriteria pengujian adalah $\mathrm{H}_{0}$ diterima apabila signifikansi $>0,05$ artinya tidak ada pengaruh linier variabel karakter rasa ingin tahu terhadap variabel prestasi belajar posttest. Hasil uji pengaruh karakter rasa ingin tahu terhadap prestasi belajar posttest dapat dilihat pada tabel dibawahini:

Tabel 6. Anova ${ }^{a}$

\begin{tabular}{llrrrrr}
\hline & Model & Sum of Squares & df & Mean Square & \multicolumn{1}{c}{ F } & \multicolumn{1}{c}{ Sig. } \\
\hline \multirow{2}{*}{1} & Regression & 3066,061 & 1 & 3066,061 & 119,550 &, $000^{\mathrm{b}}$ \\
\cline { 2 - 7 } & Residual & 641,167 & 25 & 25,647 & & \\
\cline { 2 - 7 } & Total & 3707,227 & 26 & & &
\end{tabular}

a. Dependent Variable: Posttest_Eks

b. Predictors: (Constant), Karakter_RIT

Berdasarkan hasil yang diperoleh pada Tabel 6, uji pengaruh karakter rasa ingin tahu terhadap prestasi belajar posttest dengan menggunakan uji regresi sederhanadiperoleh nilai signifikansi $=0,000$ dimana $0,000<0,05$ sehingga $\mathrm{H}_{0}$ ditolak.
Artinya terdapat pengaruh karakter rasa ingin tahu $\left(\mathrm{X}_{1}\right)$ terhadap prestasi belajar posttest $(\mathrm{Y})$. Besarnya pengaruh karakter rasa ingin tahu terhadap prestasi belajar posttest dapat dilihat pada tabel dibawahini.

Tabel 7. Model Summary

\begin{tabular}{crrrr}
\hline Model & \multicolumn{1}{l}{ R } & R Square & Adjusted R Square & Std. Error of the Estimate \\
\hline 1 &, $909^{\mathrm{a}}$ &, 827 &, 820 & 5,0643 \\
\hline
\end{tabular}

a. Predictors: (Constant), Karakter_RIT 
Berdasarkan Tabel 6 diperoleh $\mathrm{R}$ square $=0,827=82,7 \%$, hal ini berarti prestasi belajar posttest dipengaruhioleh karakter rasa ingin tahu sebesar $82,7 \%$ dan $17,3 \%$ sisanyadipengaruhi oleh faktor lain. Selanjutnya untuk mengetahui persamaan regresinya dapat dilihat pada tabeldibawahini

Tabel 8. Coefficients ${ }^{a}$

\begin{tabular}{rrrrrrrr}
\hline & & \multicolumn{2}{c}{$\begin{array}{c}\text { Unstandardized } \\
\text { Coefficients }\end{array}$} & \multicolumn{2}{c}{$\begin{array}{c}\text { Standardized } \\
\text { Coefficients }\end{array}$} & & \\
\cline { 3 - 6 } & Model & \multicolumn{1}{c}{ B } & Std. Error & Beta & \multicolumn{1}{c}{ t } & \multicolumn{1}{c}{ Sig. } \\
\hline \multirow{2}{*}{1} & (Constant) & $-26,291$ & 9,683 & & & $-2,715$ &, 012 \\
\cline { 2 - 5 } & Karakter_RIT & 1,311 &, 120 & &, 909 & 10,934 &, 000 \\
\hline
\end{tabular}

a. Dependent Variable: Posttest_Eks

Berdasarkan Tabel 8 diperoleh nilai $\mathrm{a}=$ $-26,291$ dan $b=1,311$ sehingga persamaan regresi yaitu $\widehat{Y}=-26,291+1,311 x$. Persamaan regresi dijadikan sebagai dasar prediksi prestasi belajar posttest $(\mathrm{Y})$ jika diketahui karakter rasa ingin tahu $(\mathrm{X})$.

\section{SIMPULAN}

Berdasarkan hasil analisis dan pembahasan dapat disimpulkan bahwa hasil penelitian tentang model pembelajaran kooperatif tipe Number Heads Together terintegrasi karakter rasa ingin tahu terhadap prestasi belajar matematika siswa kelas IV SD Petompon 01 kota Semarang menghasilkan pengaruh yang signifikan. Adanyapengaruh antara karakter rasa ingin tahu terhadap prestasi belajar matematika siswa pada kelas yang menggunakan model Kooperatif tipe Numbered Heads Together yang terintegrasi dengan karakter rasa ingin tahudengan besar pengaruh $\quad 82,7 \%$ sedangkan $\quad 17,3$ persendipengaruhiolehfaktorluar.

Selain itu juga diperoleh persamaan regresi adalah $\widehat{Y}=-26,291+-26,291 x$ sehingga dapat dijadikan dasar prediksi prestasi belajar posttest (variabel dependen) jika diketahui karakter rasa ingin tahu (variabel independen).

Hasil analisis data diatas mengindikasikan bahwa model pembelajaran Numbered Hedas Together terintegrasi karakter rasa ingin tahu mampu meningkatkan karakter rasa ingin tahu dan prestasi belajar siswa secara bersama-sama.

Berdasarkan kesimpulan di atas, maka dikemukakan saran (1) Bagi guru, integrasi karakter pada pembelajaran hendaknya lebih focus dengan satu karakter disetiap pembelajaran sehingga efektif dalam peningkatan prestasi belajar siswa. (2) Peneliti selanjutnya yang ingin mengkaji penelitian serupa penelitian serupa dapat mengembangkan penggunaan model pembelajaran serta karakter yang berbeda sehingga dapat dijadikan sebagai perbandingan.

\section{DAFTAR PUSTAKA}

Huda, M. 2013. Cooperative Learning : Metode, Teknik, Struktur, dan Model Penerapan, Yogyakarta: Pustaka Pelajar.

Lickona, T. 2013. Education For Character :Mendidik untuk Membentuk Karakter. Terjemahan Juma Abdu Wamaungo. Jakarta: Bumi Aksara

Mulyana, S. 2013. Pengembangan Perangkat Pembelajaran Matematika Model Cooperative Learning Tipe STAD Bermuatan Pendidikan Karakter Pada Materi Pecahan Desimal Kelas V. Tesis. Semarang: Program Pascasarjana Unnes

PISA. 2015. PISA Result in Focus. Organization for Economic Cooperation and development 
(https://www.oecd.org/pisa/pisa-2015results-in-focus.pdf ). Diunduh 1 Juli 2017

Pujiastuti. 2012. Pengembangan Perangkat Pembelajaran Matematika Model Cooperative Group Investigation Bermuatan Pensdidikan Karakter untuk Meningkatkan Kemampuan Pemecahan Masalah Matreri Himpunan Siswa Kelas VII. Tesis. Semarang: Program Pascsarjana Unnes

Rusilowati, A., Hartono., \& Supriyadi. 2012. Pengembangan model pembelajaran Better Teaching and Learning Berkarakter untuk Membekali Kompetensi Pedagogi Mahasiswa Calon Guru. Jurnal Penelitian Pendidikan, 29 (2): 83-92

Sekretariat Jendral MPR RI, 2008. Undang Undang Dasar Negara Republik Indonesia Tahun 1945. Jakarta: Majelis Permusyawaratan Rakyat Republik Indonesia.

Suharto. 2013. Pembelajaran Matematika dengan Pendekatan Kontekstual Bermuatan Pendidikan Karakter Untuk Meningkatkan Kemampuan Komunikasi Matematis Materi Program Linier Kelas XI. Tesis. Semarang: Program Pascsarjana Unnes

Sukestiyarno. 2014. Statistika Dasar. Yogyakarta : Andi Offset

Sukestiyarno. 2015. Integrasi Nilai Pendidikan Karakter. Suara Merdeka 27 Februari 2015. Diakses tanggal 21 April 2017.

Wibowo, T. 2010. Pentingnya Pendidikan Karakter Dalam Dunia Pendidikan. Diakses dari http://www.pendidikankarakter.com/pe ntingnya-pendidikan-karakter-dalamdunia-pendidikan/ (diunduh 29 Januari 2016) 